\title{
Implementation of Marketing Communications for Haircos Cosmetics
}

\author{
Biyan Yessi Wilujeng ${ }^{1 *}$, Mutiah², Octaverina \\ Kecvara Pritasari ${ }^{3}$ \\ 1,2,3 Universitas Negeri Surabaya \\ Corresponding author : email biyanyesi@unesa.ac.id
}

\begin{abstract}
Haircos Cosmetics is a type of hairtonic developed by universities. The product has been through laboratory tests and in collaboration with the cosmetic industry. Haircos that have been produced in large quantities must be marketed to meet the people's need for natural products. As a new product, of course, Haircos competes with similar products that first got a place in people's hearts. Therefore, this research was conducted with the aim of knowing the marketing communication strategy of Harircos products as a new product so that it can be known and interested by the public. This study uses the $4 \mathrm{P}$ marketing communication theory, namely product, price, place, promotion, as the basic basis for a marketing communication strategy used by a commercial product. This theory is the basis for the analysis of researchers in looking at the marketing communication strategy carried out by the founder of Haircos cosmetics. This research is a case study, with data collection through interviews and consumer surveys. This is done to see the uniqueness of the strategy carried out by the founder and team inintroducing new products to the market. The results showed that implementation of marketing communications is enough to highlight the uniqueness and quality aspects of the product, giving a price to the consumer, so the location is not yet widespread marketing of which do not reach the market share. In promotional activities, Haircos does not maximize performance on digital promotions, such as social media and E-commerce. This study suggests that Haircos cosmetic products make a careful business plan to reach the target market.
\end{abstract}

\section{Keywords: Haircos, Marketing Communication, Product, Promotion}

\section{INTRODUCTION}

HAIRCOS cosmetic product is a product of higher education innovation by a lecturer in the Department of Tatarias with a grant from DIKTI. HAIRCOS cosmetic products are formulated from natural ingredients, these products have a quality that is not inferior to products produced by the cosmetic industry. HAIRCOS Cosmetics has been through continuous research and laboratory tests. Currently, HAIRCOS is slowly moving towards a company that has business innovation because business model innovation (BMI) concerns the firms' core business rather than specific products [1]. So the hope is that in the future

HAIRCOS will become a start-up company that focuses on health and medicine in the form of hair tonic products. HAIRCOS is a hair tonic that uses natural ingredients, namely fragrant pandan extract. Fragrant pandan is a plant native to Indonesia that is used as the mainingredient in making HAIRCOS hair tonic products. HAIRCOS products try to highlight the characteristics of natural ingredients to answer the current cosmetic trend that focuses on the concept of back to nature. HAIRCOS has developed a product in collaboration with PT Kreasi Multi Rejeki in 2019, this collaboration produces 2000 pes products that are ready for distribution. HAIRCOS's readiness to enter the market is very reasonable, in addition to quality products, HAIRCOS cosmetic products have received brand certification, label industrial designcertification, packaging industry certification and have gonethrough product testing and received a distribution permit from BPOM, with BPOM NA number 18201000175. In laboratory tests and tests HAIRCOS products are a categoryof types of health and medicinal products that have good quality, not inferior to competitors in the market but quality alone is not enough, Universities that support HAIRCOSthat want to start as a startup company need to communicate their products so that they can compete and be accepted by the target community, as one of the goals of producers is to issue innovative products made from natural ingredients that are beneficial to society. For this reason, so that this 
product can enter the market and society, especially women, because women are potential consumers for this product. Women are the target of cosmetic products, on the other hand can be a mediator for cosmetic manufacturers in marketing their products [2] HAIRCOS products also target cosmetic shops and Vocational High Schools of Makeup, so a marketing communication strategy is a must for this new product.

New product development (NPD) is the complete process of bringing a new product to market [3]. A new product developed as a higher education innovation product may have difficulty entering the public's awareness due to the lack of media use for product publication compared to similar products issued by the industry. Therefore, developing a marketing communication strategy is a must. In the marketing communication strategy there are four important aspects that can be done, namely the product itself, the product is a marketing object offered to the market to meet consumer needs [4]. Products have diverse properties and characters and potential products are products that are able to grab the attention of consumers. Product reviews are critical high- scope non-marketing cues for consumers to obtain useful product information from various perspectives [5]. In addition to highlighting its advantages, products must also pay attention to packaging, packaging is omnipresent in modern production, distribution and consumption systems [6]. So goodpackaging is informative packaging for consumers. The second aspect must pay attention to the location of the sale. a strategic sales location, easily accessible to potential buyers is the best way to sell products.

This marketing location needs to be communicated through various media to attract wider attention and allow more visitorsor buyers. Currently location is no longer the main thing, because product sales can be done through online media, one of which is social media which has been widely used to selland promote the brand of a product. Promoting brands and other marketing activities through social media doesn't cost thefirm so much then it is widely evaluated as the most convenient instrument to market products to the target segment [7]. In the early stages for a new product or new brand such as HAIRCOS, promotion is quite good if consumers become aware of the new product or new brand [8]. Product promotion can also be done through advertising, because advertising is one of the marketing communication mixes that can attract the attention of a wide audience [9]. The thirdaspect is determining the price, determining the price of the product will greatly affect the success of the company to make a profit. HARICOS Cosmetics provides a price based on the sacrifices that have been made in producing these products. The price that HAIRCOS sets is according to the quality of the product. Then the fourth aspect, namely promotion, this activity is the most important component for communicating products to the market. Promotions can make consumers know that a company is launching a product, the way the company does promotions must be able to tempt consumers to make purchases. One of the determinants of how the company's product promotion is done is the amount of funds spent. But the funding factor is not the only way to be able to promote ourproducts well. Products can be promoted in a smart and preciseway, including highlighting the uniqueness and advantages of the product and directly targeting market segments. Furthermore, additional aspects, namely, human resources (HR), physical evidence, process.

In a marketing communication strategy, all activities carriedout must be considered carefully, so that the goals of the company can be realized because that is why skilled human resources are needed in their fields. People in the company play an important role in making product innovations, pricing analysis, location selection and promotional activities, so that all these aspects can run smoothly and successfully. The physical evidence factor is currently a demand for products, companies must clearly display the advantages and uniqueness of their products, so the clarity of composition, laboratory tests and even halal labels must be accessible and proven by consumers. All these aspects must go through a goodmanagement process, including the element of service to consumers because the basic logic of marketing is to understand consumers [10]. If marketing communicationactivities are carried out with good management, then all marketing objectives have a greater chance of success.

\section{METHODS}

This research uses the library method, by collecting data from relevant research, journals and references from the internet. The data were collected by taking into account research keywords, research subjects in this case the development of cosmetic product marketing, citations fromrelevant marketing book sources

\section{RESULTS AND DISCUSSION}

\subsection{The Unique Of Haircos Cosmetic Products}

Hair as a crown not only serves as a protection for the head from adverse environmental conditions, but also as an attraction as well as a symbol of beauty. Beauty comes from health and health will be obtained from cleanliness, therefore the scalp and hair need care so that they remain clean and healthy. Hair care is not enough just to use shampoo and conditioner, because hair is a living cell and needs to be maintained, 

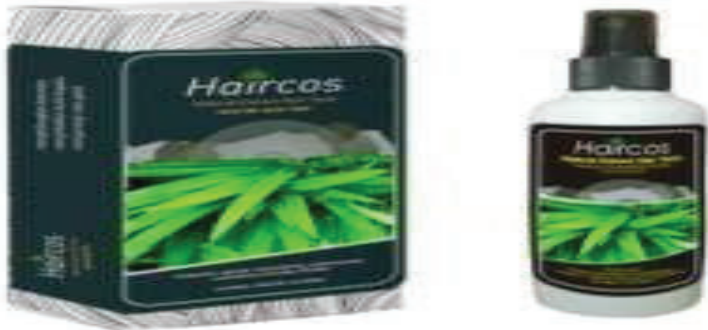

Figure 1. Haircos product packaging is

treated and given fertilizer so that it can grow healthy and beautiful. One way is to use a hair grower commonly called a hair tonic. Fragrant pandan is a plant whose leaves are often used as food additives, generally as a green dye and flavoring agent. Regular use it can reduce dandruff on the scalp. Equipped with menthol which gives a cooling sensation to the scalp, as well as pro vitamin B5 which is very suitable for healthy hair.

Haircos helps treat hair and scalp, reduces dandruff, refreshes the scalp and reduces itching. Haircos utilizes local products from the fragrant pandan plant to become hairtonic. The HAIRCOS product (Natural Hair Tonic Using Fragrant Pandan Extract (Pandanus Amaryllifolius)) is a commercially ready product. produced by PT Kreasi Multi Rejeki. HAIRCOS product (Hair Tonic Using Extract Natural Pandan Wangi (Pandanus amaryllifolius)) is a privately owned team through the research and development program CPPBT 2017. The specifications of products as follows
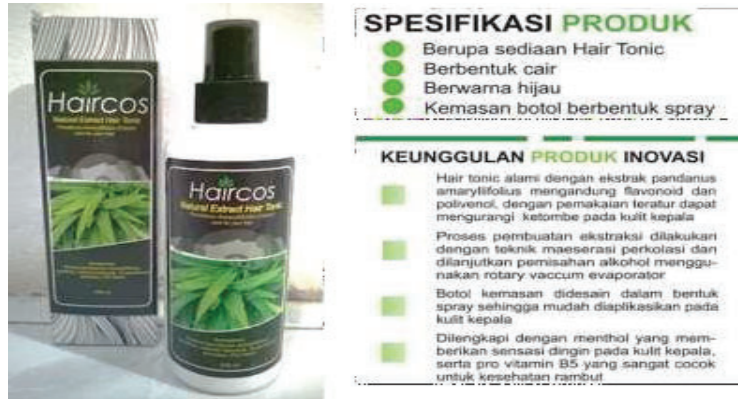

Figure 2. Product Specifications

In the first phase has been conducted organoleptic (seen from the color, homogeneity, aroma, stickiness) from the results of this test obtained a percentage of $10 \%$ of pandan extract because seen from the aroma it is not too strong, the color is more attractive and the results are homogeneous. (2) Next, carry out patent registration: fill in the patent form and then obtain the application number, formality test, public test, substantive test and improvement. At this time the patent has been granted. (3) From the results of the CPPBT, researchers have carried out phytochemical tests, $\mathrm{Ph}$ tests, and shelf-life tests. The results of these tests are worthy of product prototypes to be introduced to Vocational High Schools and beauty associations, then the brand of this product will be granted because it has been registered with TM status for registration number. the announcement of BRM1784A, the product also already has a KI type of Industrial Design labeland packaging, and currently the position has been granted. (4) From the results of Product Innovation Research through Pandan Extract Bacterial Test, Perfume Bacteria Test, COA, MOA, obtained a distribution permit from BPOM BPOM NA 182010000175. In general, the company emphasizes the uniqueness of the product in the aspect that the product is the result of research and is a product made from natural ingredients, with The main ingredient composition ispandan in large presentation quantities.

\subsection{Haircos Product Pricing}

Pricing of a product is very important to get a successful profit. In determining the price of HAIRCOS products, the management team conducts research by comparing the prices of competitors' products in the market and based on the production costs incurred. The following prices are set for HAIRCOS

Table 1. Price Identification

\begin{tabular}{|c|c|}
\hline Scheme & Marketing value (in rupiah) \\
\hline Sold directly to consumers & Rp 50,000/bottle \\
\hline Resellers & Rp. 48.000/bottle \\
\hline $\begin{array}{l}\text { UNESA residents } \\
\text { (students, } \\
\text { lecturers, alumni) }\end{array}$ & Rp. 48.000/bottle \\
\hline Special day ( $10 \%$ discount $)$ & Rp. 45.000/bottle \\
\hline Makeup Vocational School & Rp. 45.000/bottle \\
\hline Sales System & Buy 10 Free 1 \\
\hline $\begin{array}{r}\text { Buy } 1 \text { Get } 1 \text { Free for special } \\
\text { day }\end{array}$ & $\begin{array}{r}\text { Kartini Day, Mother's Day, } \\
\text { Beautiful date, Valentine's } \\
\text { Day, Hari Raya, }\end{array}$ \\
\hline
\end{tabular}

Table 2. Price Identification with Competitors

\begin{tabular}{|c|c|c|c|}
\hline \multirow[b]{2}{*}{$\begin{array}{c}\text { Aspect } \\
\text { s of } \\
\text { compa } \\
\text { rison }\end{array}$} & \multicolumn{3}{|c|}{ Product Photos } \\
\hline & ing & 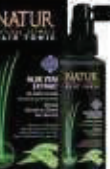 & $\left(\begin{array}{l}10 \\
1 \\
1\end{array}\right.$ \\
\hline $\begin{array}{l}\text { Bottle } \\
\text { size }\end{array}$ & $100 \mathrm{ml}$ & $90 \mathrm{ml}$ & $\begin{array}{c}120 \\
\text { mlbottle }\end{array}$ \\
\hline $\begin{array}{l}\text { Price } \\
\text { Per }\end{array}$ & Rp. 50,000 & $\begin{array}{c}\text { Rp. } \\
63,000\end{array}$ & $\begin{array}{c}\text { Rp. } \\
160,000\end{array}$ \\
\hline $\begin{array}{l}\text { Price } \\
\text { per } \\
\text { milli }\end{array}$ & Rp. 500 & $\begin{array}{l}\text { Rp. } \\
700\end{array}$ & $\begin{array}{c}\text { Rp. } \\
1333.3\end{array}$ \\
\hline
\end{tabular}


If you look at the price comparison in the table above, then the price of HAIRCOS products with competitors' products is still competitive. This price determination also considers the marketing scope, at this stage the company first penetrates the regional market as many as $1000 \mathrm{pcs}$, this is done because HAIRCOS is a new brand.

In addition to selling products in the market, the company's goal to distribute products in limited quantities is as a market research effort, to see consumer responses to these products. Furthermore, the company sells products online and offline through a network of Vocational Cosmetology schools and cosmetic shops. As for pricing based on market reach, it canbe seen in the following table.

Table 3 Pricing based on Market

\begin{tabular}{|r|r|r|}
\hline $\begin{array}{r}\text { Reach } \\
\text { Marketing } \\
\text { reach } \\
\text { Marketing }\end{array}$ & $\begin{array}{r}\text { volume } \\
\text { Marketing }\end{array}$ & value (in rupiah) \\
\hline Regional & $1000 \mathrm{pcs}$ & $\mathrm{Rp} 50.000 / \mathrm{bottle}$ \\
\hline National & $500 \mathrm{pcs}$ & Rp. $50.000 /$ bottle The \\
\hline
\end{tabular}

company also makes a price scheme in order to meet all product distribution channels. The following is a table of price schemes strategy is not only for profit, but also as a company research effort to see the response of potential consumers to this new brand. From the results of the data obtained that although the level of pricing has providedprice variations, buyers are not affected to buy. However, the product manager is still trying to provide variations in the determination of the product so that in the future there will be no news that the product is more expensive or cheaper and does not match the quality it has.

\subsection{Haircos Product Promotion}

Promotion activities are closely related to the dissemination of information to be conveyed to consumers, promotions can be called advertisements, product advertisements are very influential on the level of product sales. advertisement will have effect on customer's attitude and buying behavior [11].

HAIRCOS carries out product promotions through exhibition activities and social media Instagram with the@haircos_biyan account, this is due to limited costs so that the promotions carried out by haircos arenot optimal. The exhibition has become a reliable promotional activity, from the period 2017 -2020 it has been carried out 5 times. The exhibition was held at Grandcity mall Surabaya, Diandara Surabaya, Technopark Veteran University, exhibition at the 2018 International Conference Icracoss forum and again exhibiting at Grandcity mall Surabaya. Next, make concessional sales at the UNESA business incubator with the traditional marketing communication concept, Instead of the traditional marketingcommunication concept, the sender conveys a message to a receiver through coding, noise and decoding processes [12] If you pay attention to the Haircos exhibition, it is holdingan exhibition in a quite strategic location but product promotion has not yet expanded. Promotion through digital media and social media is not optimized. If funds for promotion are minimal, marketing performance must be improved, marketing performance can be through independent promotions such as word of mouth, maximizing online sales services and direct sales. However, the management of Haircos has not maximized these efforts, this is due to the lack of good management, and the minimal number of personnel. The following is an exhibition that hasbeen carried out by the founder of Haircos

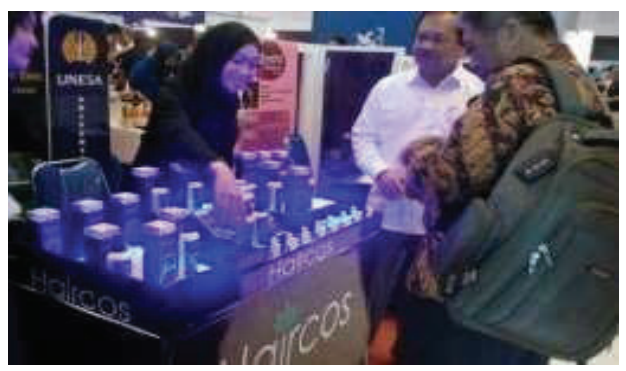

Figure 3. The exhibition at Grandcity Mall Surabaya

Efforts to attract consumers' attention have not been successful. When the exhibition was held at the Grandcity Mall Surabaya, not many visitors came to the Haircos stand. Likewise for traditional sales through the UNESA business incubator.

\section{CONCLUSION}

The conclusion of this paper is that the implementation of the marketing communication mix has been carried out buthas not been optimal. The implementation includes: 
1. HAIRTONIC products have highlighted their advantages and uniqueness, namely with natural ingredients from native Indonesian plants that have properties suitable for hair health

2. Determination of logical prices in accordance with product quality

3. Promotion is still traditional, namely through exhibitions in public spaces. So that many consumers are not familiar with HAIRCOS products.

With this lack of implementation, HAIRCOS must maximize the performance of marketing communications so that the ideals of the future business (Star up Company) that are expected to be realized.

\section{ACKNOWLEDGMENT}

We would like to thank the Faculty of Social Sciencesand Law at Universitas Negeri Surabaya for organizing this conference and providing the opportunity for our articles to be published

\section{REFERENCES}

[1] S. Baloutsos, A. Karagiannaki and I. Mourtos, "Business Model Generation for Industry 4.0: A "Lean Startup" Approach," The International Technology Management Review, vol. 9, no. 1, pp. 3445, 2020.

[2] S. Suharnanik, "Women and Make-Up: The Dilemma of Bourdieu's SubjectivismObjectivism on Social Media," The Journal of Society and Media, vol. 4, no. 1, pp. 1630, 2020.

[3] P. Suwannaporn and M. Speece, "Continuous learning process in new product development in the Thai foodprocessing industry," British Food Journal, vol. 102, no. 8, pp. 598-614, 2000.

[4] A. Hermawan, Komunikasi Pemasaran, Jakarta: Erlangga, 2012.

[5] K.-a. (. Byun, M. Ma, K. Kim and T. Kang, "Buying a New Product with Inconsistent Product Reviews from Multiple Sources: The Role of Information Diagnosticity and Advertising," Journal of Interactive Marketing, vol. 55, pp. 81-103, 2021.

[6] F. Fulconisa and B. Philipp, "Packaging scorecard for closed-loop logistics systems:" in 14th International Symposium in Management, 2018.

[7] G. D. Marin and C. Nilă, "Branding in social media. Using LinkedIn in personal brand communication: A study on communications/marketing and recruitment/human resources specialists perception," Social Sciences \& Humanities Open, vol. 4, no. 1, pp. 1-8, 2021.

[8] S. A. Terence, Integrated Marketing Communications in Advertising and Promotion, Jakarta: Salemba Empat, 2014.

[9] A. R. Dwiatmaja and P. S. Perbawani, "Endorser Laki-Laki Produk Kosmetik Perempuan Dan Pengaruhnya Terhadap Sikap Khalayak," Jurnal Komunikasi, vol. 15, no. 2, pp. 75-90, 2021.

[10] Q. Xu, "Dynamic Interaction Mechanism Model Between Market Competition, Marketing Innovation and Enterprise Innovation," in Proceedings of the 3rd International Conference on Culture, Education and Economic Development of Modern Society (ICCESE 2019), 2019.

[11] P. Keikhosrokiani, N. Mustaffa, M. I. Sarwar and N. Zakaria, "E-Torch: A Mobile Commerce Location-Based Promotion System," The International Technology Management Review, vol. 3, no. 3, pp. 140-159, 2013.

[12] Å. Finne and C. Grönroos, "Rethinking marketing communication: From integrated marketing communication to relationship communication," Journal of Marketing Communications, vol. 15, no. 2, pp. 179-195, 2009. 